\title{
On the Plant Communities of Farm Land.
}

\author{
BY \\ R. G. STAPLEDON, M.A., \\ Botanist, Agr. Dept., University of Wales, Aberystwyth.
}

INTRODUCTION.

$\mathrm{T}$ is proposed in the present paper to give some account of observations 1 made over a period of eight years on the weeds found under various - farm crops, including land put down to grass for various short periods and fields that have 'run down' to more or less permanent grass without the addition of seeds, or with a very inadequate sowing. Most of the work was carried out on the Cotswolds $\left(360^{\prime}-700^{\prime}\right)$ and in Mid-Wales $\left(350^{\prime}-1200^{\prime}\right)$; a few observations have also been made near Holsworthy, Devonshire, and near Greenhithe, Kent.

Method of Study. Endeavour has been made to study the weed flora in terms of whole communities and not as isolated species; and to supplement careful observations by a more accurate method of procedure. Two statistical methods have been employed throughout the whole period of the work.

(a) Specific Frequency. This method is used on arable land and occasionally on grass-land. It is practically identical to that employed by Rhaunkiaer, which has been explained by Smith (8) in his review of that author's 'Life Forms and Statistical Methods'. The method has been described by the present writer elsewhere (10 and 11); its essence is to record the species found on a large number of small unit-areas, without paying any attention to the abundance of individual species per each unitarea. A mesh $6^{\prime \prime} \times 6^{\prime \prime}$ is used and dropped at chance on the ground; the names of all the species occurring in each reading are carefully noted. The area to be examined is traversed across two diagonals and from 50 to 200 readings taken. The results given are recorded against each species in terms of the number of its occurrences per Ioo readings.

For purposes of publication it is, however, found more convenient to tabulate the frequencies on a scale of IO; species with frequencies below I are marked $\mathrm{o}$, if occasional; $\mathrm{s}$, if scarce or solitary; and $\mathrm{r}$, if of quite exceptional occurrence.

(b) Percentage Frequency. This method, originally devised by Armstrong (1), is advantageously employed upon grass-land. It has been explained elsewhere (11). Small unit-areas (turfs $6^{\prime \prime} \times 6^{\prime \prime}$ ) are removed

[Annals of Botany, Vo1. XXX. No. CXVII. January, 1916.] 
from the field to be investigated, taken to the laboratory, the species separated out, and the number of plants belonging to each species is then counted and the results given as a direct percentage.

Specific frequencies have been taken on over 75 fields and several hundred have been examined altogether.

When frequencies or percentage figures are not available the species have been classified according to the following grouping, which experience suggests corresponds to the frequencies given against each :

\begin{tabular}{|c|c|c|}
\hline om & e.g. frequencies & $7-9$ (Io is very exceptional) \\
\hline $\mathrm{bu}$ & ", & $3^{-6}$ \\
\hline req & ", & $I-2$ \\
\hline al, & ", & less than I and as before \\
\hline & " & " \\
\hline e & " & " \\
\hline
\end{tabular}

Treatment of the Subject. It will be convenient to deal with the subject-matter under two distinct heads. Part I. The Weeds of Arable Land; that is to say, the communities found under root crops, cereals, and 'seeds'. By 'seeds' is here understood leys which are sown down with a mixture of grass and clover seeds for one year only, or if sown for a longer period, till the end of the first year. The above communities are under the direct control of man, and owing to the exigencies of the rotation are shortlived and consequently do not afford materialf or the study of the progressive stages in the colonization of bare land. Part II. The Weeds of Grass-land. This includes the communities found on long duration leys and on permanent grass, and affords material for the study of the progressive changes which occur in the colonization of land under the constant influence of grazing animals. For the sake of comparison two cases will also be given of the colonization of bare land from which stock have been withheld.

\section{PART I.}

\section{The WeEds of Arable Land.}

Under this heading it is proposed to make the following comparisons:

I. The aggregate arable flora of the Cotswolds with that of Mid-Wales.

II. The results from Mid-Wales and the Cotswolds with those obtained elsewhere.

III. The arable flora of Mid-Wales above and below 800 feet.

IV. The weed flora under the several crops in the rotation.

In order to facilitate these comparisons the frequencies found for a large number of species in both localities and in various places in the rotation are set out in the subjoined table (Table I). 
Stapledon.-On the Plant Communities of Farm Land. 163

TABLE, I.

DISTRIBUTION OF THE CHIEF SPECIES IN MID-WALES AND THE COTSWOLDS

\begin{tabular}{|c|c|c|c|c|c|c|c|c|c|}
\hline Chief Species. & 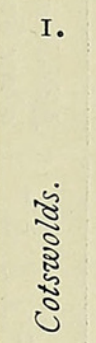 & 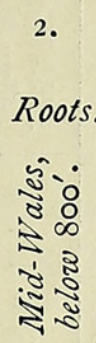 & 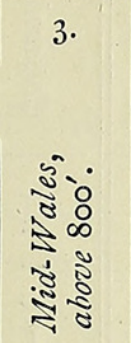 & 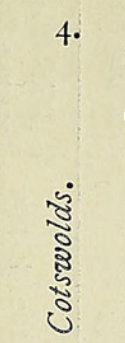 & 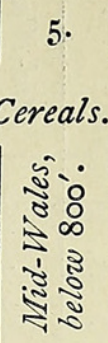 & 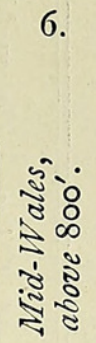 & 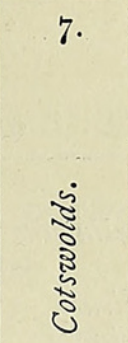 & 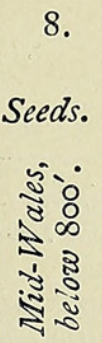 & 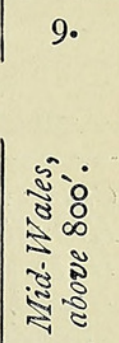 \\
\hline Ranunculus repens & 2 & I & $0-6$ & I & $3(6)$ & $3-9$ & o & $0-2$ & $0-4$ \\
\hline$R$. parviflorus & 0 & $\mathrm{r}$ & - & $\mathrm{s}$ & $\mathrm{r}$ & - & - & - & - \\
\hline$R$. arvensis & $\mathrm{r}$ & - & - & $\mathrm{s}-\mathrm{O}$ & - & - & - & - & - \\
\hline Papaver Rhoeas & o & - & - & $2(5)$ & - & - & - & - & - \\
\hline$P$. dubium & - & - & - & $\mathrm{s}-\mathrm{O}$ & $\mathrm{r}$ & - & - & - & - \\
\hline Fumaria officinalis & $S-I$ & $\mathrm{r}$ & - & $3-6(9)$ & $r$ & - & $\mathrm{r}$ & - & - \\
\hline$F \cdot$ pallidiflora & - & $0(2)$ & $\mathrm{r}$ & - & O-I & - & - & - & - \\
\hline Erophila verna & $\mathrm{r}$ & - & - & (4) & $\mathrm{r}$ & - & - & - & - \\
\hline Brassica arvensis & O-I & s (2) & o & $2-4$ & $0(5)$ & I (6) & - & - & s \\
\hline$B$. nigra & 0 & - & - & I & - & - & - & - & - \\
\hline Capsella Bursa-pastoris & 2 & o & o & I & $\mathrm{s}$ & - & r & - & - \\
\hline Thlaspi arvense & 0 & - & - & 0 & - & - & - & - & - \\
\hline Viola tricolor (agg.) & $O-I$ & $\mathbf{I}$ & I & I & 2 & 0 & 3 & I & $0-I(3)$ \\
\hline Silene Cucubalus & $\mathrm{r}-\mathrm{O}$ & - & - & $I-3$ & s & $\mathrm{r}$ & - & - & - \\
\hline Lychnis alba & 0 & - & - & $\mathrm{I}-2$ & s & $\mathrm{r}$ & - & - & - \\
\hline L. Githago & $\mathrm{r}$ & - & - & 0 & $\mathrm{r}$ & - & - & - & - \\
\hline Stellaria media & $2(4)$ & $3-5$ & $3-6(9)$ & $2-5$ & 3 & 2 & $\mathrm{r}$ & $\mathbf{r}$ & $0-(5)$ \\
\hline Arenaria serpyllifolia & 0 & $\mathrm{~s}$ & - & 0 & $\mathrm{r}$ & $\mathrm{r}$ & $0-3(6)$ & $r$ & - \\
\hline Spergula arvensis & - & I & $I-9$ & - & $I-4$ & $4-6$ & - & $\mathbf{r}$ & - \\
\hline Hypericum pulchrum & - & - & - & - & - & s-o & - & - & - \\
\hline Geranium molle & o & $\mathbf{S}$ & - & s & o & s-o & I (4) & o (3) & $\mathrm{S}-2$ \\
\hline G. dissectum & s & $\mathrm{r}$ & - & s-o & o & $\mathrm{S}$ & o (3) & o (2) & $\mathrm{S}-2$ \\
\hline Erodium cicutarium & - & - & - & - & - & - & (3) & - & - \\
\hline Trifolium minus & - & - & - & - & - & - & - & $0-3$ & $1-4(7)$ \\
\hline Ornithopus perpusillus & - & - & - & - & - & $\mathrm{s}-\mathrm{O}$ & - & - & - \\
\hline Vicia Cracca & - & - & s & - & - & s & - & - & - \\
\hline Lotus corniculatus & - & - & $\mathbf{r}$ & - & - & s & - & - & $\mathrm{s}-\mathrm{O}$ \\
\hline Lathyrus pratensis & - & - & $\mathbf{r}$ & - & - & s & - & - & $\mathbf{r}$ \\
\hline Potentilla erecta & - & - & 0 & - & - & (6) & - & - & $\mathrm{s}$ \\
\hline Alchemilla arvensis. & $\mathrm{r}$ & $\mathrm{s}-\mathrm{O}$ & $\mathrm{r}$ & s-2 & o & $\mathrm{r}$ & $I-3$ & 2 & $S-I(2)$ \\
\hline Scandix Pecten-Veneris & I & - & - & 0 & - & - & - & - & - \\
\hline Aethusa Cynapium & $\mathrm{r}$ & - & - & I & $\mathrm{r}$ & - & - & - & - \\
\hline Daucus Carota & $\mathbf{s}$ & $\mathrm{r}$ & - & - & - & - & - & 0 & - \\
\hline Galium saxatile & - & - & - & - & - & $0-2$ & - & - & s \\
\hline G. Aparine & 2 & $\mathrm{r}$ & - & I & $\mathbf{r}$ & - & o & $\mathrm{r}$ & - \\
\hline Sherardia arvensis & s & 0 & s & - & o & - & 3 & I & $\mathbf{s}$ \\
\hline Scabiosa arvensis & $\mathrm{r}$ & - & - & $\mathrm{I}-2$ & $\mathrm{r}$ & - & - & - & - \\
\hline S. succisa & - & - & - & - & s & $o(3)$ & - & - & - \\
\hline Bellis perennis & $\mathrm{r}$ & s & I & - & 3 & $2-9$ & s & I & $0-2(3)$ \\
\hline Gnaphalium uliginosum & - & - & 3 & - & - & - & - & - & - \\
\hline Achillea Ptarmica & - & - & $\underline{-}$ & - & - & o & - & - & - \\
\hline Chrysanthemum segetum & - & 2 & $0-4(7)$ & - & $0-4$ & $1-7$ & - & - & - \\
\hline Matricaria inodora & $\mathrm{r}$ & o & $\mathrm{s}$ & - & $\mathrm{s}$ & $r$ & - & $\mathbf{r}$ & - \\
\hline Senecio vulgaris & I & I & o & 0 & o & $\mathrm{r}$ & $\mathbf{r}$ & - & - \\
\hline Cnicus lanceolatus & - & - & - & - & - & - & o & o & - \\
\hline C. arvense & 3 & I & s & 3 & 2 & o & - & - & - \\
\hline Centaurea nigra & - & s & o & - & - & $s-3$ & - & - & - \\
\hline C. Cyanus & - & - & - & o & - & - & - & - & - \\
\hline Cichorium Intybus & - & - & - & - & - & - & $\mathrm{r}$ & o & s \\
\hline Lapsana communis & - & o & s & 0 & o & s & - & $s-0$ & s \\
\hline
\end{tabular}




\begin{tabular}{|c|c|c|c|c|c|c|c|c|c|}
\hline Chief Species. & 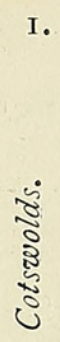 & 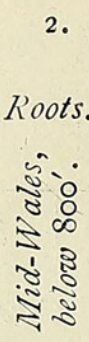 & 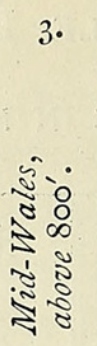 & 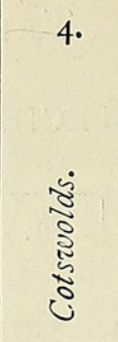 & 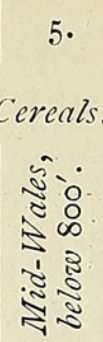 & 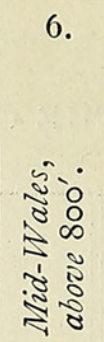 & 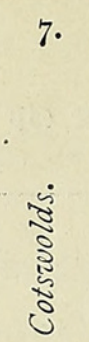 & 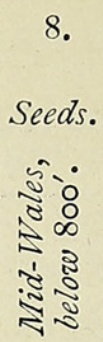 & 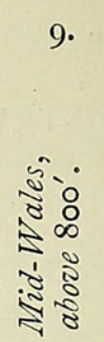 \\
\hline Crepis virens & 0 & I & 2 & - & - & I & 0 & $I-2$ & $r-0$ \\
\hline Hieracium umbellatum & - & - & - & - & - & $s-2$ & - & - & - \\
\hline H. boreale & - & - & - & - & - & $\mathrm{s}-\mathrm{O}$ & - & - & - \\
\hline Hypochoeris radicata & - & $\mathrm{r}$ & o & - & $\mathrm{s}$ & $I-4$ & $\mathrm{~s}$ & 2 & $0-2$ \\
\hline Taraxacum officinale & $\mathrm{r}$ & $\mathrm{s}$ & o & I & $\mathrm{s}$ & 0 & 2 & $\mathrm{~s}$ & $o(3)$. \\
\hline Sonchus oleraceus & I & 2 & $\mathrm{~s}$ & o & - & - & - & - & - \\
\hline S. arvensis & $\mathrm{s}$ & o & o & $I-2$ & 0 & $\mathrm{~s}$ & - & - & - \\
\hline Legousia hybrida & $\mathrm{r}$ & - & - & $0-3(4)$ & - & - & - & - & - \\
\hline Anagallis arvensis & o & $\mathrm{s}$ & - & 0 & $2(5)$ & - & $\mathrm{r}$ & $\mathrm{r}$ & - \\
\hline Myosotis arvensis & 0 & s (2) & $\mathrm{r}$ & I & 0 & $\mathrm{r}$ & 3 & 0 & $\mathrm{r}-\mathrm{s}$ \\
\hline Lithospermum arvense & - & - & - & 0 & - & - & 0 & - & - \\
\hline Convolvulus arvensis & 6 & o & - & $4(7)$ & o & - & $\mathrm{r}$ & - & - \\
\hline Veronica hederaefolia & 2 & $\mathrm{~s}$ & - & 7 (I0) & $\mathrm{s}$ & - & $\mathrm{r}$ & - & - \\
\hline$V$. agrestis & $\mathrm{s}$ & I (4) & $\mathrm{r}$ & $\mathrm{s}$ & 2 & $\mathrm{r}-\mathrm{O}$ & - & o & $0-2$ \\
\hline$V \cdot$ polita & - & 0 & o & - & 0 & o & - & - & - \\
\hline V. Tournefortii & I & - & - & I & - & - & - & - & - \\
\hline$V$. arvensis & $\mathrm{r}$ & $\mathrm{s}$ & - & $\mathrm{s}$ & o & - & s (2) & 0 & - \\
\hline$V$. serpyllifolia & $\mathrm{s}$ & $\mathrm{s}$ & - & 0 & $\mathrm{r}$ & - & $0-1$ & $r-s$ & - \\
\hline Bartsia Odontites & - & - & - & $\mathrm{s}$ & - & - & $\mathrm{s}$ & $\mathrm{r}$ & - \\
\hline Mentha arvensis & - & o & I & - & I & $0-2$ & - & s-o & $\mathrm{s}$ \\
\hline Clinopodium vulgare & $\mathrm{s}$ & - & - & I & - & - & - & - & - \\
\hline Calamintha officinalis & - & 3 & $0-2$ & - & o & o & - & $\mathrm{s}$ & $\mathrm{s}-\mathrm{o}$ \\
\hline Prunella vulgaris & $\mathrm{s}$ & o & 0 & $\mathrm{~s}$ & I & $I-2$ & I & $2-(6)$ & $0-5$ \\
\hline Stachys arvensis & - & $I-2$ & $\mathrm{r}$ & - & $I-2$ & $\mathrm{r}$ & - & - & - \\
\hline Galeopsis Tetrahit & - & I & $2-(4)$ & - & 0 & $\mathrm{I}-2$ & - & - & - \\
\hline G. versicolor & - & - & 0 & - & - & $\mathrm{s}$ & - & - & - \\
\hline Lamium amplexicaule & 2 & $\mathrm{r}$ & - & $o(6)$ & $\mathrm{s}$ & - & $\mathrm{r}$ & - & - \\
\hline L. purpureum & 2 & - & - & $\mathrm{s}$ & $\mathrm{s}$ & - & $\mathrm{r}$ & - & - \\
\hline Plantago major & $\mathrm{s}$ & $\mathrm{s}$ & $\mathrm{s}$ & $\mathrm{s}$ & $\mathrm{s}$ & $\mathrm{s}$ & $\mathrm{s}$ & $\mathrm{rr}$ & $\mathrm{r}$ \\
\hline P. media & - & - & - & 0 & - & - & $\mathrm{s}$ & - & - \\
\hline P. lanceolata & $\mathrm{r}$ & $\mathrm{s}$ & I & $\mathrm{s}$ & o & I & I & $I-5$ & 7 \\
\hline Scleranthus annuus & - & - & - & - & o & $\circ(5)$ & - & - & - \\
\hline Chenopodium album & 3 & 2 & $\mathrm{~s}$ & -2 & $\mathrm{~s}$ & - & - & - & - \\
\hline Atriplex patula & $\begin{array}{l}5 \\
2\end{array}$ & 2 & o & $\mathrm{o}$ & $\mathrm{o}$ & - & - & - & - \\
\hline Polygonum Convolvulus & 2 & I & $0-I$ & $2-5$ & o & $\mathrm{s}$ & - & - & - \\
\hline P. aviculare (agg.) & 3 & I & 0 & 3 & I & o & $\mathrm{r}$ & $r-s$ & - \\
\hline P. Persicaria & 3 & 4 & $\mathrm{I}-(9)$ & $\mathrm{o}$ & 0 & $I-(4)$ & - & $\mathrm{r}$ & s-o \\
\hline Rumex Acetosella & - & 2 & 3 & - & 3 & $6-(9)$ & - & $0-2$ & $0-4$ \\
\hline Euphorbia Helioscopia & 2 & $\mathrm{~s}$ & 0 & o & o & $\mathrm{s}$ & $\mathrm{r}$ & - & - \\
\hline E. exigua & $\mathrm{o}$ & $\mathrm{r}$ & - & - & - & - & - & - & - \\
\hline Urtica urens & $\mathrm{r}$ & - & - & - & - & $\mathrm{r}$ & - & - & - \\
\hline Allrum vineale & - & - & - & $\mathrm{s}$ & - & - & - & - & - \\
\hline Luzula erecta & - & - & - & - & - & $0-2$ & - & - & $\mathrm{r}-\mathrm{s}$ \\
\hline Alopecurus myosuroides & - & - & - & o & - & - & - & - & - \\
\hline Agrostis spp. & I & $\mathrm{I}-(7)$ & 3 & $\mathrm{~s}$ & $1-6$ & $2-8$ & o & $\mathrm{I}-(3)$ & $0-2$ \\
\hline Aira caryophyllea & - & - & $\underline{-}$ & - & $\mathrm{r}-\mathrm{s}$ & o & - & - & $\mathrm{r}$ \\
\hline A. praecox & - & - & - & - & $\mathrm{r}-\mathrm{s}$ & o & - & - & $\mathrm{r}$ \\
\hline Holcus lanatus & $\mathrm{s}$ & $0-3$ & I & o & 0 & 3 & $\mathrm{~s}$ & 2 & $0(3)$ \\
\hline Avena strigosa & - & - & $0-3$ & - & - & $0-3$ & - & - & - \\
\hline Arrhenatherum tuberosum & - & o & $I-4$ & - & $\mathrm{s}$ & $I-2$ & - & - & - \\
\hline Poa trivialis & - & - & - & $0-2$ & - & - & - & - & - \\
\hline Festuca ovina & - & - & - & - & - & $\mathrm{I}-2$ & - & _ & $\mathrm{r}$ \\
\hline Bromus hordeaceus & $\mathrm{r}$ & - & - & 0 & - & - & o & 0 & 0 \\
\hline Agropyron repens. & 2 & . & - & 2 & $\mathrm{~s}$ & - & $\mathrm{r}$ & - & - \\
\hline
\end{tabular}


For some species the range of frequency is given (thus e.g. 4-8); in most cases the average frequency only is given (e.g. s, 5 , or 8 ); in some cases as well as the average frequency an exceptionally high frequency is given (e.g. 3 the normal and (8) the exceptional figure).

\section{Comparison of the Flora of the Cotswolds with that of Mid-Wales.}

The soils of the two districts are very different; that of the Cotswolds is derived from the Great Oolite and is a highly calcareous loam.

The soils investigated in Mid-Wales are derived from Ordovician Shales and give rise to a thin, very stony soil, which in wet weather is very sticky (due to a high percentage of fine silt) and in dry weather tends to cake badly and form pan; under favourable conditions, however, it works into a friable loam.

Below (Table II) is given a typical chemical and mechanical analysis of each soil. For the Mid-Wales figures I am indebted to my colleague Mr. Jones Griffiths; the Cotswold results are quoted from Kershaw's (5) analyses.

\section{TABLE II.}

SYNOPSIS OF MECHANICAL AND CHEMICAL ANALYSES OF COTSWOLDS AND MID-WALES SOILS.

\begin{tabular}{|c|c|c|}
\hline & $\begin{array}{l}\text { Mechanical Analyses. } \\
\text { Mid-Wales. }\end{array}$ & Cotswolds. \\
\hline $\begin{array}{l}\text { Fine Gravel } \\
\text { Coarse Sand }\end{array}$ & $\begin{array}{l}20 \cdot 3 \\
\text { I } 3 \cdot 5\end{array}$ & $\begin{array}{l}I \cdot 5 \\
I \cdot 6\end{array}$ \\
\hline Fine Sand & $8 \cdot 4$ & $5^{\cdot 6}$ \\
\hline Coarse Silt & I $2 \cdot 6$ & I $3^{\circ} 4$ \\
\hline Fine Silt & $20 \cdot 8$ & I $5 \cdot 3$ \\
\hline Clay & $7 \cdot 8$ & I $3 \cdot 8$ \\
\hline & $\begin{array}{c}\text { Chemical Composition. } \\
\text { Mid-Wales. }\end{array}$ & Cetsrenlds \\
\hline Nitrogen & 0.39 & $0 \cdot 3^{8}$ \\
\hline Lime $(\mathrm{CaO})$ & 0.15 & I I $\cdot 27$ \\
\hline Phosphoric Acid $\left(\mathrm{P}_{2} \mathrm{O}_{5}\right)$ & 0.008 & $0 \cdot 24$ \\
\hline Potash $\left(\mathrm{K}_{2} \mathrm{O}\right)$ & 0.86 & $0.4 \mathrm{I}$ \\
\hline Available Phosphoric Acid & 0.002 & 0.007 \\
\hline Available Potash & 0.04 & O.OII \\
\hline
\end{tabular}

The above figures show the Mid-Wales soil to be very deficient in lime and phosphoric acid, the Cotswold soil to be very rich in lime and relatively rich in phosphoric acid. Considering the marked difference in the two soils the number of species which occur in the one district and not in the other are comparatively few. The following are, however, characteristic: 
Stapledon.-On the Plant Communities of Farm Land.

MID-WALES.

Spergula arvensis.

Ornithopus perpusillus.

Chrysanthemum segetum.

Stachys arvensis.

Galeopsis versicolor.

Scleranthus annuus.

Rumex Acetosella.
Cotswolds.

Ranunculus arvensis.

Thlaspi arvense.*

Papaver Rhoeas.

Lychnis Githago.*

Erodium cicutarium.*

Scandix Pecten-Veneris.*

Legousia hybrida.

Lithospermum arvense.

Clinopodium vulgare.

Allium vineale.*

* These species have been noted by Salter ( 7 ) as occurring in Cardiganshire, but have not been seen on the arable lands investigated.

A number of species are far more abundant on the farm land of one district than the other. The following are good examples :

Mid-WALES.

Ranunculus repens.

Calamintha officinalis.

Galeopsis Tetrahit.

Polygonum Persicaria.

Arrhenatherum tuberosum.
COTSWOLDS.

Silene Cucubalus.

Erophila verna.

Brassica nigra.

Geranium spp.

Aethusa Cynapium.

Scabiosa arvensis.

Lamium amplexicaule.

L. purpureum.

Convolvulus arvensis.

Alopecurus myosuroides.

Agropyron repens.

It is interesting in this connexion to note the behaviour of certain closely allied plants; the following are the species of three common genera for the two districts :

Mid-WALES.

Fumaria pallidiflora.

Veronica agrestis.

Plantago lanceolata.

\section{COTSWOLDS.}

F. officinalis.

Veronica hederaefolia.

$V$. Tournefortii.

P. media.

These results will be further alluded to in the next section. 


\section{Comparison of Results obtained on the Cotswolds and in Mid-Wales with those recorded elsewhere.}

The weeds of arable land have in the past been studied chiefly as individuals and not as communities; as long ago as 1845 Bravender (2) published an interesting paper on these lines, and this was followed in 1855 by a more exhaustive article by Buckman (4). Recently, however, Brenchley has investigated the weed communities of arable land on the following chief geological formations, Greensand, Chalk, Gault, and Boulder Clay, and has tabulated the results obtained in three important papers. ${ }^{1}$ It will be of interest here to contrast the behaviour of some of the chief species found in the two districts under consideration with the relationships observed for the same species elsewhere, both by Brenchley and the present writer.

$A$. Cotswolds. It might be expected that the highly calcareous loams over Oolite on the Cotswolds would carry a very similar weed flora to the soils over Chalk; that the flora differs in many essentials will, however, be seen from the following comparison.

The following species are all common on the Cotswolds; but concerning each Brenchley in her most recent paper (Norfolk, $3 c$ ) remarks as follows :

Ramunculus repens.* 'Distributed on all soils, but seldom seen on chalk.' Erodium cicutarium. 'Distributed on sand and very light soils.'

Alchemilla arvensis. 'Characteristic of light and sandy soils, very rare on chalk.'

Scandix Pecten-Veneris.* 'Found on all soils, except chalk, though seen occasionally on chalky loam.'

Myosotis arvensis.* 'Chiefly on sand and loam, rare on chalk.'

Bartsia Odontites.* 'Chiefly associated with loam, never seen on chalk.'

Veronica hederaefolia. 'Associated with sand and light sandy loams, absent from clay and chalk. Once dominant on loam.'

Polygonum Convolvulus. 'Seen on chalky loam, but never on chalk.'

* These four species Brenchley finds in the Wiltshire and Bath districts are characteristic of Chalk.

Thus it appears that all the above species, although in many districts essentially non-Chalk plants, may be associated with highly calcareous as well as with more normal loams. Veronica hederaefolia is particularly interesting, for on the Cotswolds it is one of the commonest weeds, where it generally has a frequency corresponding to a dominant position, yet 'it is absent from chalk and only once dominant on loam'. 


\section{Stapledon.-On the Plant Communities of Farm Land.}

A number of species common on Chalk are also typical Cotswold weeds; some, however, appear to have rather different frequencies over Oolite than on other calcareous soils. The distribution of the following plants on the Cotswolds may be contrasted with their distributions recorded elsewhere by Brenchley; the remarks in inverted commas after each species are quoted from this author.

Papaver Rhoeas. 'Often dominant', true of the Cotswolds.

Fumaria officinalis. 'Occasionally dominant', frequently dominant on the Cotswolds.

Lychnis Githago. 'Scarce in distribution', occasionally plentiful on the Cotswolds.

Silene Cucubalus. 'Twice dominant on sand, usually distributed or occasional', often abundant on Cotswolds.

Legousia hybrida. 'Never dominant, often scarce', frequently very abundant on Cotswolds.

Neither Linaria vulgaris nor Cichorium Intybus are plentiful on the Cotswolds.

It would thus appear that the weed communities of the Cotswolds, especially when the frequencies of the chief contributing species are taken into consideration, are decidedly characteristic, and that they differ both from the communities found on ordinary loams and from those found over Chalk.

B. Mid-Wales. These soils are acid in reaction and consequently decidedly 'sour'; they are by no means sands; they are intermediate between loam and clay, and are thus 'sour' soils of a heavier nature than those investigated by Brenchley. ${ }^{1}$ Heavy 'sour' clays have been studied by the present writer near Holsworthy, Devon, and peats have come under observation in Mid-Wales, while the flora on sands have been examined near Greenhithe, Kent. It is possible, therefore, to contrast the communities found on the various grades of 'sour' soil.

Below (Table III) is given the range of frequencies for the chief species found on four grades of 'sour' soils : (1) Peat (Mid-Wales); (2) Noncalcareous clay (Devon); (3) Non-calcareous stiff loam (Mid-Wales); (4) Sand (deduced from Brenchley's papers and the present writer's personal observations in Kent).

1 See Brenchley, (3c), p. I 49 . 
Stapledon.-On the Plant Communities of Farm Land. I69

TABLE III.

TO COMPARE THE WEED COMMUNITIES FOUND ON FOUR GRADES OF 'SOUR' SOIL.

I.

Chief Species.

Ranunculus repens

Papaver Rhoeas

Erophila verna

Spergula arvensis

Geranium molle

G. dissectum

Potentilla Anserina

Scabiosa succisa*

Gnaphalium uliginosum

Achillea Ptarmica*

Chrysanthemum segetum

Centaurea nigra*

Lycopsis arvensis

Echium vulgare

I'eronica hederaefolia

Mentha arvensis

Prunella vulgaris

Stachys palustris

$S$. arvensis

Galeopsis Tetrahit

$G$. versicolor

Scleranthus annums

Polygonum Persicaria

Rumex Acetosella

Euphorbia exigua

Aira caryophyllea

A. praecox

Bromus hordeaceus
2.

Non-

Calcareous

Clay.

a-d

-

a-d

-

$r$

a-d

$r$

$o-f$

o-f

$o-f$

-

$-$

$\overline{f-a}$

f-a

-

$\bar{f}$

o-f

a

d

d

s-o

$\mathrm{f}$ a

-

f-a

$r$

o-f

o-f

$f-a$

$\mathrm{f}$

$r$

f-a

$-$

$-$

$f-d$

f-a

$\mathrm{f}-\mathrm{a}$

$\mathrm{f}$

f

-

a

f

a

o

o

r
3.

Non-

Calcareous

sticky loam.

$\begin{array}{cc}\mathrm{f}-\mathrm{a} & \mathrm{o}-\mathrm{f} \\ - & \mathrm{a}-\mathrm{d} \\ \mathrm{r} & \mathrm{o}-\mathrm{f} \\ \mathrm{a}-\mathrm{d} & \mathrm{a}-\mathrm{d} \\ \mathrm{r}-\mathrm{f} & \mathrm{f}-\mathrm{a} \\ \mathrm{r}-\mathrm{f} & \mathrm{r} \\ \mathrm{f}-\mathrm{a} & \mathrm{o}-\mathrm{f} \\ \mathrm{r} & \mathrm{r} \\ \mathrm{o}-\mathrm{f} & \mathrm{f}-\mathrm{a} \\ \mathrm{r} & - \\ \mathrm{a}-\mathrm{d} & \mathrm{d} \\ \mathrm{o}-\mathrm{f} & \mathrm{r} \\ - & \mathrm{o} \\ - & \mathrm{o} \\ \mathrm{r} & \mathrm{o}-\mathrm{f} \\ \mathrm{f} & \mathrm{r}-\mathrm{o} \\ \mathrm{f}-\mathrm{a} & \mathrm{o} \\ \mathrm{f} & - \\ \mathrm{f} & - \\ \mathrm{f}-\mathrm{a} & - \\ \mathrm{f} & - \\ \mathrm{f} & \mathrm{a}-\mathrm{d} \\ \mathrm{f}-\mathrm{a} & \mathrm{f}-\mathrm{a} \\ \mathrm{a} & \mathrm{a}-\mathrm{d} \\ \mathrm{o} & \mathrm{r} \\ \mathrm{o} & \mathrm{f}-\mathrm{a} \\ \mathrm{s} & \mathrm{f} \\ \mathrm{s} & \mathrm{f}\end{array}$

* These species, although most common on marshy pastures, have also been found on arable land.

The behaviour of the following species is of particular interest. Spergula arvensis is seen to be by no means essentially a sand plant; it may be abundant on all 'sour' soils and dominant on clay and sand alike. Chrysanthemum segetum is also distributed over 'sour' soils generally; although rare on clays, it may be dominant on sticky loams and frequent on peat. Rumex Acetosella is most abundant on peat and sand. Potentilla Anserina and Gnaphalium uliginosum are both favoured by winter puddling; the latter plant has been commonly found about gates, and near Greenhithe was the only plant on the floor of an orchard, on sand on which pigs had been kept all the winter.

Scleranthus anmus has also been found on all grades of 'sour' soil, even attaining to an abundant position on clay. Ramunculus repens may completely overrun peat soils.

It appears from a general consideration of the above table that the communities judged as a whole are more symptomatic of soil type than are the presence or absence of relatively few index plants; and it must be 


\section{I70 Stapledon.-On the Plant Communities of Farm Land.}

urged that, although Spergula arvensis and Chrysanthemum segetum are certain indications of 'sourness', they are not confined to sands alone. It will be noted that less than 25 per cent. of these 'sour' soil plants are calcifuge species, suggesting that circumstances influencing the available water of the habitat, aeration, and other environmental factors exert as much influence as the absence of lime as such.

It is of interest to observe that the Mid-Wales soils, although ranging from clay to stiff loam, do not include Ranunculus arvensis in their weed communities, and that such plants as Stachys palustris, Euphorbia exigua, Galium Aparine, Potentilla reptans, Agropyron repens, and Papaver Argemone are not at all generally distributed. Euphorbia Helioscopia, on the other hand, is probably as frequent on these soils as on those of a more calcareous nature.

\section{The Communities of Mid-Wales above and below 80o'.}

Smith and Moss (9) and Moss (6) have pointed out that the limit of Wheat cultivation corresponds roughly with the limits of a number of weeds. Wheat is not grown on an extensive scale in the area now under consideration, but a number of farmers at altitudes below about $800^{\prime}$ grow a small breadth for home consumption. Oats are grown up to about I,400', and Barley is often to be seen considerably above $\mathrm{I}, 000^{\prime}$. Moss (6) has shown that the altitudinal limit of wheat cultivation is different on the various soils of the Peak district, but the average range is from about $500^{\prime}$ to $900^{\prime}$. In this district the general method of husbandry is usually somewhat different above about $800^{\prime}$ than below it, so that the $800^{\prime}$ contour is a useful line of demarcation for purposes of comparison. The chief differences in the farming at high altitudes, apart from the absence of Wheat, are that the Brown Oat (Avena strigosa) is more extensively grown; Mangolds are only grown to a slight extent; and the grass is left down for a longer period than is the case at lower elevations. Furthermore the arable farming is usually negligent; the hoe is frequently inactive; and the grass and clover seeds used are poor in quality, full of impurities, and inadequate. The effect of these primitive methods of husbandry on the weed flora will be shown to be considerable. ${ }^{1}$

Moss (6) has listed some forty odd species for the area studied in the Peak district as not occurring on both the Wheat and no-Wheat zone, practically all of these being absent from the higher elevations.

A comparison of columns 3, 6, 9 (no-Wheat zone, i.e. above $800^{\prime}$ ) with 2, 5, 8 (Wheat zone, i.e. below 800') in Table I shows the following differences for Mid-Wales :

1 It is perhaps most marked in the case of the grass-land. See Part II, 
Stapledon.-On the Plant Communities of Farm Land. I 7 I

(a) Species only occurring at the Lower Elevations; but which even then are in most cases rare or occasional.

Europhila verna.

Papaver dubium.

Scabiosa arvensis. Aethusa Cynapium.

Convolvulus arvensis.
Veronica hederaefolia.

$V$. arvensis.

Lamium amplexicaule.

L. purpureum.

Euphorbia exigua.

(b) Species rare or exceptional at the Higher Elevations.

Fumaria pallidiflora.

Silene Cucubalus.*

Lychnis alba.*
Arenaria serpyllifolia.

Bromus hordeaceus.

(e) Species decidedly more abundant at the Lower Elevations.

Alchemilla arvensis.

Galium Aparine.*

Sherardia arvensis.*

Matricaria inodora.*
Lapsana communis.*

Sonchus oleraceus.

S. arvensis.

Anagallis arvensis.

Myosotis arvensis.

Stachys arvensis.

Chenopodium album.*

(d) Species frequently more abundant at the Higher Elevations.

Ramunculus repens.

Spergula arvensis.*

Hypericum pulchrum. $\dagger$

Vicia Cracca. $\dagger$

Lotus corniculatus. $\dagger$

Lathyrus pratensis. $\dagger$

Potentilla erecta. $\dagger$

Chrysanthemum segetum.*
Hieracium umbellatum. $\dagger$

H. boreale. $\dagger$

Galeopsis Tetrahit.

$G$. versicolor.

Rumex Acetosella.*

Lusula erecta. $\dagger$

Arrhenatherum tuberosum.

Festuca ovina.†

(e) Species which Moss has noted as absent on the no-Wheat zone in the Peak district ; but which in Mid-Wales are freely distributed above $800^{\prime}$.

Geranium molle**

G. dissectum.*

These species do not, however, attain to their full

Veronica agrestis.

Mentha arvensis.

luxuriance at the higher elevations.

* These species are all more or less common impurities in clover seeds. See Stapeldon, R. G. (12).

$\uparrow$ These species are normally weeds of grass-land. See p. I72. 


\section{I72 Stapledon.-On the Plant Communities of Farm Land.}

It thus appears that in Mid-Wales there are only about twenty-five species which belong more essentially to the Wheat than to the no-Wheat zone, and that the majority of the abundantly occurring weeds are common to both zones. A number of the species which occur to only a slight extent at the higher elevations undoubtedly owe their origin to being introduced with the seed mixtures. Commonly occurring impurities have been marked with an asterisk in the above lists; many of these, although normally weeds of young leys, may not appear till the land has been again ploughed, when they are manifest as isolated weeds in the corn, but being unsuited to high elevations remain small and stunted. ${ }^{1}$

The reason for the greater abundance of certain species at the higher than the lower elevations is probably not climatic.

Thus the more frequent dominance of Spergula arvensis, Chrysanthemum segetum, Ramunculus repens, and Rumex Acetosella is simply due to absence of the hoe; whilst neglect in the use of the horse-hoe would account for the prominent position of Arrhenatherum tuberosum. Similarly Galeopsis Tetrahit ${ }^{2}$ and $G$. versicolor, normally waste-place plants, are able to flourish amidst neglected root crops. The presence of such plants as Hypericum pulchrum, Vicia Cracca, Potentilla erecta, and others marked with a dagger under section $(d)$ is explained as follows:

These plants do not occur to any extent under roots, but are often common under Oats. Oats always follow grass in the rotation at high elevations; in many cases, however, the grass may have been down for eight to ten years, when it will have become very inferior, full of weeds, and of an indigenous character; many of the indigenous plants are able to survive the process of ploughing and again appear under the first Oat crop, although not ordinarily speaking arable land weeds. Avena strigosa, grown as a cereal, occurs as an abundant weed in the following root crop.

\section{The Communities under the several Crops in the Rotation.}

The weed flora found under different crops is partly influenced by the manner of growth and partly by the tillage operations connected with the husbandry of the particular crop. Under good farming arable land should be free from a number of familiar perennials, while a well-tended root crop should at all times be associated with but a meagre weed community; under indifferent farming, however, 'roots' present very favourable opportunities for the spread of weeds, namely, a comparatively rich soil and abundance of bare ground.

There can be no doubt also that arable land communities are affected throughout the whole rotation by impurities sown with the grasses and clovers; this is particularly noticeable in districts where high farming

1 e. g. Galium Aparine, Myosotis arvensis, and Silene Cucubalus.

2 Seeds of this plant are frequently introduced with Oats, 
is not the rule. The influence of impurities on the communities at high elevations in Mid-Wales ${ }^{1}$ has already been referred to, and probably accounts for the sporadic appearance of weeds such as Silene Cucubalus, Caucalis nodosa, Matricaria inodora, Lapsana communis, and Galium Aparine in the arable land. It is now generally accepted that seeds of a great number of species can lie dormant in the soil for considerable periods; and it has been shown elsewhere ${ }^{2}$ that poor grass and clover samples contain the seeds of a number of weeds common to root and cereal crops, which on favourable soils and under the influence of tillage operations probably manifest themselves as considerable nuisances, and on unfavourable soils may give rise to sporadic appearances of unusual weeds.

The communities studied both on the Cotswolds and in Mid-Wales appear to be somewhat different under roots, cereals, Vetches, and 'seeds', as is shown by the following brief synopsis.

\section{(a) Cereals and Roots.}

The communities under cereals in particular have been elsewhere (10) shown to exhibit a regular seasonal change. The flora found late in June and during July (when the straw is reaching its maximum height) includes relatively fewer ground annuals than is the case earlier in the spring, and more tall, straggling, and climbing plants such as Sonchus arvensis, Polygomum Convolvulus, and Convolvulus arvensis, and also plants the seed of which germinates later in the season, e.g. Aethusa Cynapium.

The flora on the stubble after the corn has been harvested is often an exceedingly rich one, and is more or less a replica of that occurring in the seedling corn early in the spring. For the purpose of the present comparisons the communities found under cereals from March till the middle of June are considered as representative.

Certain species appear to be rare under roots; on the Cotswolds this is true of

\section{Ranunculus arvensis. \\ Erophila verna. \\ Lychnis Githago.}

Bartsia Odontites.

Plantago media.

Poa trivialis.

Under poor farming on some of the Mid-Wales soils, certain species, which are not normally common in the root crop elsewhere, may be fairly plentiful:

Alchemilla arvensis.

Bellis perennis.

Lapsana communis.
Matricaria inodora.

Plantago lanceolata.

Holcus lanatus.

1 Will be discussed in greater detail when dealing with grass-land.

2 See Stapledon, R. G. (12). 


\title{
I74 Stapledon.-On the Plant Communities of Farm Land.
}

A few species are, as Brenchley has observed, practically confined to cereals; on the Cotswolds this is true of

\author{
Lapsana communis. \\ Poa trivialis. \\ Plantago media.* \\ * Becomes very abundant on leys that have been down for some years.
}

In Mid-Wales this distinction does not hold, but at high elevations certain indigenous grass-land plants invade the corn crop only. ${ }^{1}$

The above distinctions in terms of individual species are slight; if, however, the frequencies of some of the more abundantly occurring species are compared, it will be seen that the differences in the communities are more marked.

The following species have higher frequencies under cereals than roots: ${ }^{2}$

CoTSWOLDS.

Papaver Rhoeas.

Fumaria officinalis.

Brassica arvensis.

Silene Cucubalus.

Lychnis alba.

L. Githago.

Scabiosa arvensis.

Taraxacum officinale.

Legousia hybrida.

Lithospermum arvense.

Veronica hederaefolia.

Polygonum Convolvulus.
Mid-WALES (below 800').

Ranunculus repens.

Brassica arvensis.

Spergula arvensis.

Chrysanthemum segetum.

Rumex Acetosella.

The following species tend to have higher frequencies under roots than cereals :

COTSWOLDS.

Capsella Bursa-pastoris.

Senecio vulgaris.

Lamium purpureum.

Polygomum Persicaria.

Atriplex patula.

Euphorbia Helioscopia.
Mid-WaLes (below 800').

Sonchus oleraceus.

Calamintha officinalis.

Polygonum Persicaria.

Atriplex patula.

It is also noteworthy that a number of species, although not necessarily

1 See p. 171, section $(d)$, species marked with a dagger.

2 In districts where farmers sow cereals saved from their own stacks, the following weed seeds are frequent impurities: Lychnis Githago, Polygonum Persicaria, P. Convolvulus, Convolvulus arvensis, and Rumex spp. 
having higher frequencies under roots, are much more luxuriant on a wellmanured root field than they are under cereals; examples are-

Capsella Bursa-pastoris.

Stellaria media.

Senecio vulgaris.

Sonchus oleraceus.
Anagallis arvensis.

Chenopodium album. Atriplex patula.

Lamium purpureum.

At high elevations, or elsewhere where the farming is poor, differences between the root and cereal communities are not so well marked; and in this connexion it is interesting to note that a number of more or less typical corn weeds are usually either quite sporadic in roots or absolutely overrun the crop. They can be checked by the free use of the hoe, but if this is neglected they become even more abundant than under corn. Thus the normally greater abundance of Papaver Rhoeas, Brassica arvensis, Spergula arvensis, and Chrysanthemum segetum under corn than roots is due almost entirely to immunity from mechanical disturbance.

\section{(b) Vetches.}

The communities under this crop are usually meagre, for it is essentially a 'smothering' crop; consequently the number of small ground annuals is inconsiderable. The presence of larger perennials will depend on the state of cleanliness of the ground. On the Cotswolds the following plants were usually found able to compete favourably with VetchesRanunculus arvensis, Galium Aparine, Convolvulus arvensis, and Polygonum Convolvulus; and in dry seasons (e.g. I9I I) certain tall plants introduced with the seeds are sometimes successful, e.g. Brassica alba, Lychnis Githago, Saponaria Vaccaria, Limum usitatissimum, and Cannabis sativa.*

* Introduced with German and Russian samples of seed.

\section{(c) 'Seeds.'}

The weed communities under seeds are more characteristic than those associated with other crops. Weeds under 'seeds' have to contend with the strong inter-specific competition set up by the growth of several million seedlings of plants having decidedly gregarious characteristics. ${ }^{1}$ These plants form a considerable tangle on the ground by the first autumn after sowing. It follows that the weed flora will be considerably affected by the degree of excellence with which the seeds 'take.' This will depend

1 e.g. from about 4.5 to 5.5 million for short leys and 18 million for long duration pastures. Observations on the Cotswolds and in Mid-Wales have shown that I million weed plants to the acre is an exceptionally high figure under cereals and roots. Oats give about 3 million and Barley 2 million sown seedlings to the acre, so that the aggregate competition under Oats is between something under 4 million and Barley something under 3 million seedlings per acre, and there is also much more space between the cereal seedlings than between those of the grasses and clovers. 


\section{76 Stapledon. On the Plant Communities of Farm Land.}

chiefly on $(a)$ the season, $(b)$ the soil, $(c)$ the appropriateness of the seed mixture used.' In dry seasons and on poor soils the 'take' is likely to be poor, in consequence of which the weed flora will include a number of species not usually associated with good leys. The following synopsis may be given of the weeds met with under 'seeds':

(a) Those which do not occur elsewhere in the rotation.

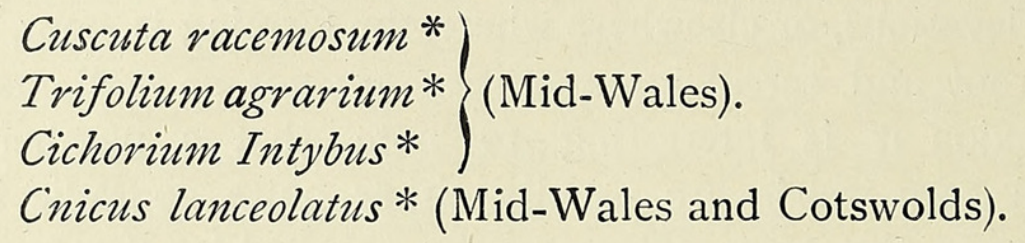

(b) Those which under good 'takes' are normally found to have high frequencies-frequencies for many of the species higher than found elsewhere in the rotation.

Ranunculus repens.*

Viola tricolor (agg.).

Arenaria serpyllifolia.

Cerastium spp.*

Geranium molle**

G. dissectum.*

Erodium cicutarium.

Alchemilla arvensis.

Trifolium minus.*
Bellis perennis.

Cnicus lanceolatus.*

Hypochoeris radicata.*

Taraxacum officinale.*2

Myosotis arvensis.*

Veronica serpyllifolia.

Prunella vulgaris.*

Plantago lanceolata.*

(c) On poor soils and under moderate ' takes' the following are frequent:

Lotus uliginosus (Mid-Wales on wet soils).

Chrysanthemum leucanthemum* (Mid-Wales and Cotswolds).

Veronica agrestis (Mid-Wales).

Rumex Acetosella* (Mid-Wales, especially on peat).

Holcus lanatus* (Mid-Wales and Cotswolds).

Bromus hordeaceus (Cotswolds).

Agrostis spp. (Mid-Wales).

(d) In dry seasons and wherever the 'take' may have been for any reason very poor the following are prone to occur:

Capsella Bursa-pastoris.

Fumaria officinalis (Cotswolds).

Stellaria media.*

Galium Aparine.*

Veronica hederaefolia (Cotswolds).
Polygonum Persicaria.*

$P$. aviculare.

Euphorbia Helioscopia.

Agropyron repens.

1 This point will be dealt with at length under grass-land. See Part II.

2 This plant has been noted by Brenchley to be absent or rare under 'seeds'; this is by no means the case in Mid-Wales. 
(e) Species, although abundant in a district which, are quite exceptional under even the poorest ' take'.

Spergula arvensis.*

Sonchus arvensis.

Chrysanthemum segetum.*
Legousia hybrida.

Chenopodium album.*

* The seeds of species thus marked in the above lists are all more or less plentiful in poor seed mixtures.

It appears from a consideration of the above lists that except for Cnicus lanceolatus, which is perhaps a typical weed of both young leys and older grass-land, the only plants met with under 'seeds' that do not occur elsewhere in the rotation are certain exotics ${ }^{1}$ introduced with the clover seeds and which can grow under grass-land conditions.

If the plants mentioned under headings $(b)$ and $(c)$ are regarded as being characteristic weeds in 'seeds' on soils that suit them, it would seem that the following growth forms are well adapted to compete with the sown turf-forming and gregarious species.

\section{A. Plants which produce Seedlings capable of attaching themselves closely to the ground.}

\section{(a) Annuals.}

The most successful annuals are those which either in the first or second generation form little cushions on the ground (they appear thus in the late autumn); these autumnal plants do not, however, flower till the following spring-that is to say, they are, under the conditions obtaining, hibernal annuals. Good examples are: Viola tricolor (agg.) (often from second generation), Alchemilla arvensis (usually first generation), Trifolium minus (first or second generation), and Myosotis arvensis (usually first generation).

Even more successful are those definitely hibernal annuals which form strong rosettes on the ground during the first autumn, e.g. Gevanium molle and $G$. dissectum, and Erodium cicutarium (this plant often becomes a biennial or even a short-lived perennial).

\section{(b) Biennials and Perennials.}

The most successful are plants which during the first autumn produce considerable cushions, mats, or rosettes close on the ground, and subsequently develop a spreading or creeping manner of growth, or send up comparatively long flowering stems. Examples of the first type are Ranunculus repens, Bellis perennis, Chrysanthemum leucanthemum, Veronica serpyllifolia (shortly creeping), Prunella vulgaris, and Rumex Acetosella; and of the second, Cnicus lanceolatus, Hypochoeris radicata, Taraxacum officinale,

1 Exotic to the particular district. 
and Plantago lanceolata. It will be shown (Part II) that the majority of these plants are capable of gaining considerably on grass-land as the years go on.

\section{B. Plants the Seedlings of which do not attach themselves unusually closely to the ground.}

\section{(a) Gramineae.}

On poor soils Holcus lanatus and Agrostis spp. in Mid-Wales and Bromus hordeaceus on the Cotswolds may be fairly plentiful even in the first year of a ley, although they only become abundant as the rye grasses die off; thus these grasses can compete to some extent with the sown species.

\section{(b) Other Natural Orders.}

The commonest plants are Arenaria serpyllifolia. This annual is capable of spreading considerably over the ground, and under Sainfoin leys especially has a very gregarious habit. Veronica agrestis usually occurs on leys at high elevations in Mid-Wales; observations suggest that it may there produce a few flowers in the autumn, but none the less live over the winter and flower more freely during the following spring.

Some plants, although endowed with favourable growth forms (when judged by the above standards), are none the less rare or exceptional on leys. A good example is Agropyron repens, a tall-growing grass with an extensive system of stolons. This plant does not seem able to compete with other gregarious plants; possibly it requires more light and air than is available under grass-land conditions.

The plants which may be met with on poor leys and in dry seasons are for the most part ephemeral annuals which can thrive on bare patches, but the seedling plants of which, not having a cushion form of growth, are rapidly suppressed. when the conditions are again favourable to the spread of the grasses and clovers. Colonies of these plants are frequent where the corn has been leyed and where, consequently, the seed 'take' has been bad-very successful species then being, Stellaria media in Mid-Wales, and Veronica hederaefolia on the Cotswolds.

In conclusion, it must be pointed out that a number of weed impurities are introduced with grass and clover seeds (especially in districts where the farming is poor), but if the 'take' is good only such as are capable of growing under 'seeds' will appear to any extent in the ley; exceptionally large amounts of Geranium spp. and other species marked with an asterisk in groups $(b)$ and $(c)$ are frequently to be attributed to this cause. ${ }^{1}$

1 A number of fields in Mid-Wales have been examined in the light of the impurities found in the samples of seeds sown. 


\section{CONCLUSION.}

One object of the present paper has been to show that considerable advantages are to be gained by studying the weeds of arable land on a statistical basis, and in the light of the community as a whole. The application of this method immediately shows that, apart from anything else, species differ very much in their powers of colonization. Certain species, although they may be generally distributed over districts, are never numerically abundant ; others are, however, capable of forming considerable carpets on the ground.

For instance, Ramunculus repens, Rumex Acetosella, Spergula arvensis, and Veronica hederaefolia, and a number of other plants under congenial surroundings may have frequencies as high as 9. Euphorbia Helioscopia, Lapsana communis, and other plants, although they may grow under equally congenial surroundings, seldom attain to frequencies as high as 2. Thus when contrasting the behaviour of species under different conditions, it is necessary to have in mind their inherent capabilities as colonizers; consequently the presence of such weeds as Spergula arvensis, Ramunculus repens, \&c., in very small amount may, in certain cases, be just as or more significant than the complete absence of a species with a low habitual frequency. ${ }^{1}$ It can be shown, furthermore, that a knowledge of the habitual frequencies of species makes it possible to gauge with some degree of accuracy their behaviour under unusual seasonal or other change. For instance, on the Cotswolds in the spring of I9I2 (i. e. following the drought of I9II), a few species doubled and in some cases trebled their habitual frequencies, e.g. Lamium amplexicaule and Arenaria serpyllifolia, whilst Veronica hederaefolia everywhere attained to something approaching its maximum figure. Important, however, as it is to take frequencies into account, it is far more important to contrast whole communities, or at all events the chief contributing species of communities, rather than to interpret the influences of soil or of cropping in terms of the behaviour of certain 'index' plants; this has been emphasized in the body of the paper, and was well exemplified when considering the flora of 'sour' soils.

The results given would seem to show that the weed communities of arable land are (I) decidedly responsive to change in soil; (2) are different near the altitudinal limits of cultivation, to what they are on the same soils at lower elevations; this is, however, in part due to negligent husbandry; (3) that they are also influenced by the crop under which they grow, but that this is largely due to the husbandry associated with the various crops.

It has only been sought to compare the communities under Roots (including Swedes, Mangolds, and Potatoes), Cereals (including Wheat,

1 The presence of species with high habitual frequencies in small amount only may be due to the activity of the hoe-a source of error always to be guarded against. 


\section{I80 Stapledon.-On the Plant Communities of Farm Land.}

Oats, and Barley), Vetches and 'Seeds'. It has been pointed out that under good farming the communities with roots are meagre, but that certain species are usually more luxuriant under roots than when associated with other crops. Under poor farming the communities met with in roots and cereals do not differ much from each other. 'Seeds' have been shown to favour characteristic communities, and something definite can be asserted as to the growth forms of the generally successful plants; the nature of the community is, however, considerably influenced by success or otherwise of the sown seeds. (4) In districts where inferior and unclean seeds mixtures are used, the communities not only under the seeds, but in subsequent crops in the rotation, may be influenced to a large extent by the added impurities.

The FAUgan,

LLANBADARN,

ABERYSTWYTH.

\section{LITERATURE REFERRED TO.}

1. Armstrong, S. F.: The Botanical and Chemical Composition of the Herbage of Pastures and Meadows. Journ. Agr. Science, vol. ii, Part 3, Dec. I90\%.

2. Bravender, R. J. : On the Indications which are Practical Guides in judging of the Fertility or Barrenness of Soil. Journ. Roy. Agr. Soc., vol. v, 1845 .

3. Brenchley, W. E. : The Weeds of Arable Land in relation to the Soils on which they grow. (a) Ann. Bot., vol. xxv, Jan. I9II ; (b) vol. xxvi, Jan. I9I 2 ; $(c)$ vol. xxvii, Jan. I9I3.

4. Buckman, Prof.: On Agricultural Weeds. Journ. Roy. Agr. Soc., vol. xvi, I 855.

5. KINCH, E. : Manurial Experiments on Permanent Grass. (See pp. 2 and 3 for Mr. M. Kershaw's Chemical and Mechanical Analyses.) Royal Agr. Coll. Cirencester, Bull. No. I, I909.

6. Moss, C. E. : Vegetation of the Peak District. Camb. Univ. Press, I9I 3.

7. Salter, J. H.: Flowering Plants and Ferns of Aberystwyth and Neighbourhood. Aberystwyth, undated.

8. Sмiтh, W. G. : Raunkiaer's 'Life Forms and Statistical Methods'. Journ. Ecology, vol. i, No. i, March, I9I3.

9. —_ and Moss, C. E. : Geographical Distribution of Vegetation in Yorkshire. Part I. Leeds and Halifax Dist. Geogr. Journ., xxi, 1903.

10. Stapledon, R. G.: Notes on the Weed Flora of some Arable Land. Roy. Agr. Coll. Cirencester, Bull. No. 2, I9I0.

11. Part 2, 19I3.

12. Aberystwyth, Feb. 19I4. 


\section{$2 \mathrm{BHL}$ Biodiversity Heritage Library}

Stapledon, R. G. 1916. "On the plant communities of farm land." Annals of botany 30, 161-180. https://doi.org/10.1093/oxfordjournals.aob.a089583.

View This Item Online: https://www.biodiversitylibrary.org/item/237452

DOI: https://doi.org/10.1093/oxfordjournals.aob.a089583

Permalink: https://www.biodiversitylibrary.org/partpdf/320105

\section{Holding Institution}

Smithsonian Libraries

\section{Sponsored by}

Biodiversity Heritage Library

\section{Copyright \& Reuse}

Copyright Status: Not in copyright. The BHL knows of no copyright restrictions on this item.

This document was created from content at the Biodiversity Heritage Library, the world's largest open access digital library for biodiversity literature and archives. Visit BHL at https://www.biodiversitylibrary.org. 